\title{
Research on Creative Transformation of Traditional Chinese Culture under the Perspective of Cyber-culture
}

\author{
LuoBei \\ Ideological and Political Theory Teaching and Research Department,
}

Southwest Medical College,Luzhou,Sichuan 646000

36130831@qq.com

Keywords: Traditional Chinese Culture, Creative Transformation, Function Value

\begin{abstract}
Network cultural development of traditional culture and education concept and modalities of challenges, but also provides for the expansion of the traditional culture and education support education, dissemination of traditional cultural values, promote interaction and subjectivity play and other educational opportunities. Meanwhile traditional culture education innovation network is to achieve cultural environment of traditional cultural and educational function of ideology inevitable demand is an inevitable choice to promote the comprehensive development of students, but also the modern development of traditional culture and education of their needs. The creative transformation of traditional culture, based on the need to reform the practice of the national conditions; from the whole issue, to avoid fragmentation; be identified dialectical, adhere to critical inheritance; promote patriotism as the core national spirit, culture closed to prevent doctrine.
\end{abstract}

Project Resource: Sichuan Province philosophy and social science research base in Sichuan Culture Research Center Network 2015 annual issue (Item Number WLWH15-39) \&Luzhou City, Sichuan philosophy and social science planning issues Project 2016(Item Number LZ16A72)

\section{Theoretical Introduction of Chinese Traditional Culture}

Chinese traditional culture can be defined as: the Chinese people to create the body, in the late Qing Dynasty before the formation of the land in China and developed, with distinct characteristics and stabilizing structure, generations and affect the entire social history, grand classical culture system. Traditional culture is the history handed down, with distinct characteristics, generations and affect the entire social history, grand classical culture system. International traditional culture and foreign culture and contemporary culture there are many different, in order to show the existence of any culture are the limitations and phase.

Chinese traditional culture is generating vast land, abundant supplies, the geographical area of the country up to 960 million square kilometers of the western countries - China is the cradle, which provides very powerful natural conditions to produce traditional Chinese culture. Elite Chinese traditional culture is the birthplace of the Yangtze River and the Yellow River, China's history and culture also developed in the Yangtze River and the Yellow River Basin. However, the traditional cultural background of the birth was natural and social and human combined with each other, interactions. Culture is a human psychology, psychology is a spiritual force in the development of Chinese traditional culture, we can't ignore the psychological condition of the community. Social concept of mass psychology, political orientation, national psychology, ethics foundation of traditional culture and so determines the generation, transformation and development of Chinese traditional culture ${ }^{[1]}$.

Characteristics of traditional Chinese culture is thousands of years in the history of the 
development process of the formation, not only throughout the people's way of thinking, the traditional cultural rituals like always, there is also a system in which all kinds of literature and. Along with the reform and opening up to, with particular emphasis on the Central Committee of the Chinese traditional culture awareness and research. Therefore, put forward to build a socialist core value system as the goal is for us to carry forward the fine cultural traditions of our country, carrying forward the national spirit provides very favorable development opportunities.

\section{Cause Analysis of Modern Transformation of Chinese Traditional Culture}

Modern Transformation of Chinese Traditional Culture in modern China is the entire society, which is consistent in transition from a traditional agricultural society to modern industrial society, so it is the product of the expression of this large transition process. Change in the trend of modern times, the modern transformation of traditional Chinese culture generally undergo cultural change material level, three stages of cultural change and cultural change, the concept level system level. Essence, the impact of Western culture and Chinese traditional culture is an important factor in the vitality of reasons why Chinese traditional culture and modern transformation of Chinese society is the reality of the situation affecting its intrinsic basis for development. These factors ultimately lead to the disintegration of the reconstruction of traditional Chinese culture and the new culture of modern China ${ }^{[2]}$. Fig. 1 shows the cause analysis of modern transformation.

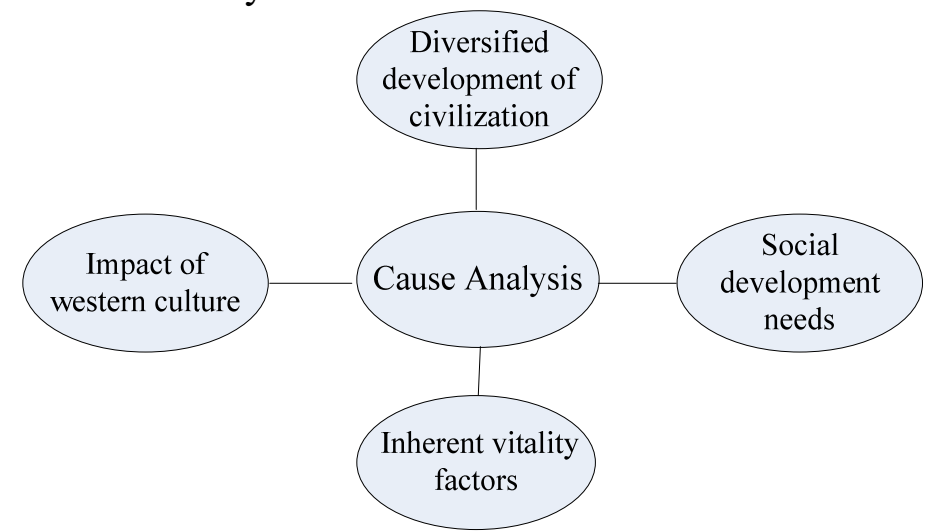

Fig. 1.The cause analysis of modern transformation

As the core of traditional Chinese culture, Confucian is an internal lack of energy inert system, it is a long-term stagnation, and only under the impact of Western culture, was forced to respond, forced to shift to modern times. In fact, it is more than the origin of civilization, the development of any civilization or culture, nation and society, so, too. The development of human civilization is diverse, due to the cultural and historical traditions of each country and the nation and facing different conditions, and will inevitably lead to the diversified development of civilization, and the existence of cultural diversity is a basic feature of human society and an important driving force for development of human civilization. At the same time, civilization is not a closed system but an open system. Chinese people can not only determines the choice of Western culture and traditional cultural content, and determine how to transform them. Evolution influence in China's largest at the time entered China in the Western.

Indeed, the Chinese traditional culture and modern culture behind the West, when the coming of Western culture, which often show quite stubborn attitude of rejection. But the interior of traditional Chinese culture and Western culture there are also fit factor. These vibrant cultural factors in the modern transformation of traditional Chinese culture also played a positive role. Chinese traditional culture is a multi-ethnic culture fused together a complex, more inclusive than the European medieval culture. This kind of competition for survival, said to explain the theory of human society is reactionary theory of the expansion of services for the colonists. But this theory spread in China has increased in crisis Chinese people's national consciousness and social reforms to provide a theoretical basis. Chinese grave national crisis of modern times also determine the way 
forward and rapidly changing modern culture Thought ${ }^{[3]}$.

\section{The Basic Principles of Creative Transformation}

Blaze new trails is the theory of Marxism, is the soul of a nation's progress, the inexhaustible power but also a prosperous country. Only always adhere to this principle, in order to deal with the past serve the present, the relationship between inheritance and development, innovation and change in order to achieve the form and content. In order to deal with traditional and modern, inheritance and development of relations in order to enable the development of traditional Chinese culture to adapt to the times, innovation and transformation in form and content ${ }^{[4]}$. Fig. 2 shows the basic principles of creative transformation.

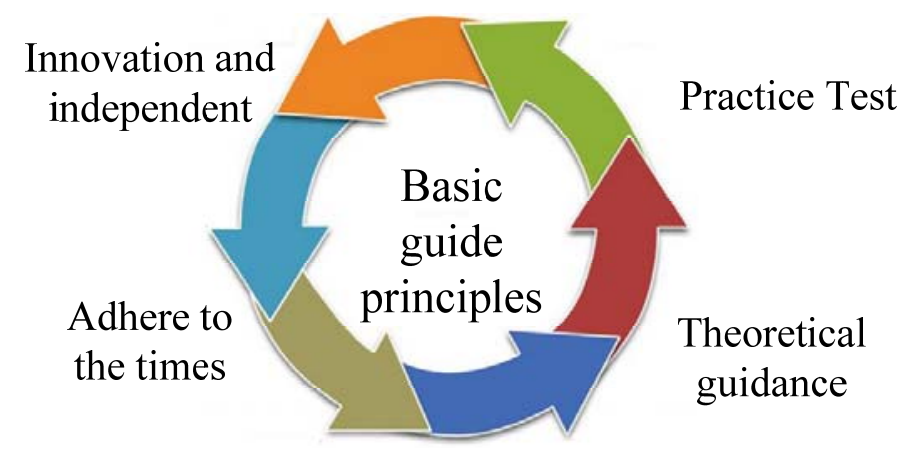

Fig. 2.The basic principles of creative transformation

The overall spirit of the traditional culture of learning can help students firmly establish the awareness of environmental protection, the relationship between man and nature proper treatment, life and learning to consciously maintain ecological balance, protect wildlife, and to better promote human natural ecological harmony, help to promote the sustainable development of our society and economy. Chinese tradition inherited the spirit of harmony and unity and cooperation to enable us to carry out socialist construction, in economic terms it is conducive to the country's economic take-off, in political terms it is conducive to national unity and solidarity of the country, the culture which is conducive the formation of "prosperity, can contribute to the process in the New spiritual civilization construction.

Strengthen the excellent traditional culture and education, not only to inherit and carry forward the fine traditional culture, but also learn from foreign advanced culture, its essence to its dregs. In this information age, friction cultural interaction and cultural globalization remote collision, the national traditional culture with its own innovation to promote recycling has the role of traditional culture only continue to inject new content, new contents will be vibrant with age vitality. However, in the process of globalization, independence is a prerequisite for a country's development, therefore, take the traditional cultural independence and unity of the organic world. Of course, culture and ideas and learn from foreign peoples, we must also take into account China's national conditions.

To carry forward and cultivate the national spirit and contemporary fine cultural traditions of the Chinese nation, based on theoretical knowledge, combined with carry out the corresponding practice. Cultivate the national spirit is inseparable from the theoretical guidance. To scientific theory to arm people with correct media guidance, imbue them with lofty ideals, and inspire them with excellent works. Only by adhering to the scientific theory to full-scale armed, in order to lay a solid theoretical foundation for the cultural qualities and scientific and cultural qualities improve intellectual tradition nationals. Only in this way, in the face of various ideologies and cultures collide with each other. We should follow the tide of economic globalization and peoples increasingly closer exchanges trends, global strategic vision, outstanding creative absorb foreign culture, growing their own, so that our national spirit and enrich the connotation.

\section{Creative Transformation of Traditional Chinese Culture}

Chinese traditional culture to achieve outstanding creative transformation and innovative 
development is inseparable from China's excellent traditional culture of confidence and well-known love of understanding. Lack of cultural confidence and confidence values, the root of the Chinese nation is lost and soul; no in-depth study and scientific understanding of the Chinese excellent traditional culture, there is much less of creativity and innovation. We only have a clear grasp of history, development context of Chinese culture, the basic trend of in-depth study of the unique creation of Chinese culture, values, distinctive characteristics, then the fine traditional Chinese culture, historical, innovation can be handy, with ease, to the problem, It will be more emboldened to do things, more confident ${ }^{[4]}$.

Creative transformation of Chinese traditional culture needs diachronic practice, with good genes traditional culture in the modern era to form an independent opinion and spirit of the Chinese nation, rather than doing long subordination of western civilization and followers. Event we can traced the remains of the coordinates of history and tracking of the times, from which to explore and collecting an instructive, and then summed up the cultural transformation of the law and the possibility of approach has necessity, in order to give our traditional culture conversion narrative positioning. In the background of globalization surging, at the intersection of multicultural and a variety of ideas, confrontation and communion, we need under the theoretical guidance of Marxism, combined with the reality of practice, the theme of the times and development mandate, and actively digging excellent Chinese traditional culture show content, promote the creative transformation of Chinese traditional culture in the life of the masses practice.

In short, the historic interpretation, critical inheritance, comprehensive and practical innovation beyond, in the creative transformation of Chinese traditional culture during each focusing on a different time dimension, the historical interpretation of the more pointed in the past, focused on the current critical inheritance What social life should inherit; comprehensive innovation and practice beyond the main point to build the future culture of the new system. These four aspects together constitute the fine traditional Chinese culture creative transformation of the basic path, but also to achieve the era of great development of socialist culture with Chinese characteristics and prosperity of the requirements.

\section{Conclusions}

Insist on the use of historical materialism, carry forward the essence of traditional Chinese culture, and strive to realize its creative transformation, which is an important task of ideological workers and temporary. Ideology and culture is reflected in the country's soft power, equal to abandon the traditional spiritual lifeline cut. Core values are the soul of cultural soft-power, and Chinese traditional culture has become an important source of Conservation socialist core values. In short, efforts to achieve creative transformation of traditional Chinese culture, it is to transcend time and space, beyond the country, full of timeless charm, culture and spiritual values promote contemporary up to inherit the fine traditional culture and spirit of the age, based on their own and the world of contemporary Chinese cultural innovation spread out.

\section{References}

[1] Routledge Handbook of Public Diplomacy, Edited by Nancy Snow and Phillip M. Taylor, Routledge Taylor and Francis Group, New York and London, 2009.

[2] Philip Seib, America's New Approach to Africa: AFRICOM and Public Diplomacy, Figueroa Press, Los Angeles, 2009.

[3] The Practice of Public Diplomacy: Confronting Challenges Abroad, William A. Rugh, Palgrave Macmillan, 2011.

[4] Robert Banks, A Resource Guide to Public Diplomacy Evaluation, Figueroa Press, Los Angeles, 2011.

[5] Barry A. Sanders, A Strategic Approach To U.S. Public Diplomacy, Figueroa Press, Los Angeles, 2011. 